American Journal of History and Culture
(ISSN:2637-4919)

\title{
Diplomatic Victory of the Kosovo Liberation Army
}

\author{
Dr. Lulzim Nika
}

Member of the Organization of American Historians

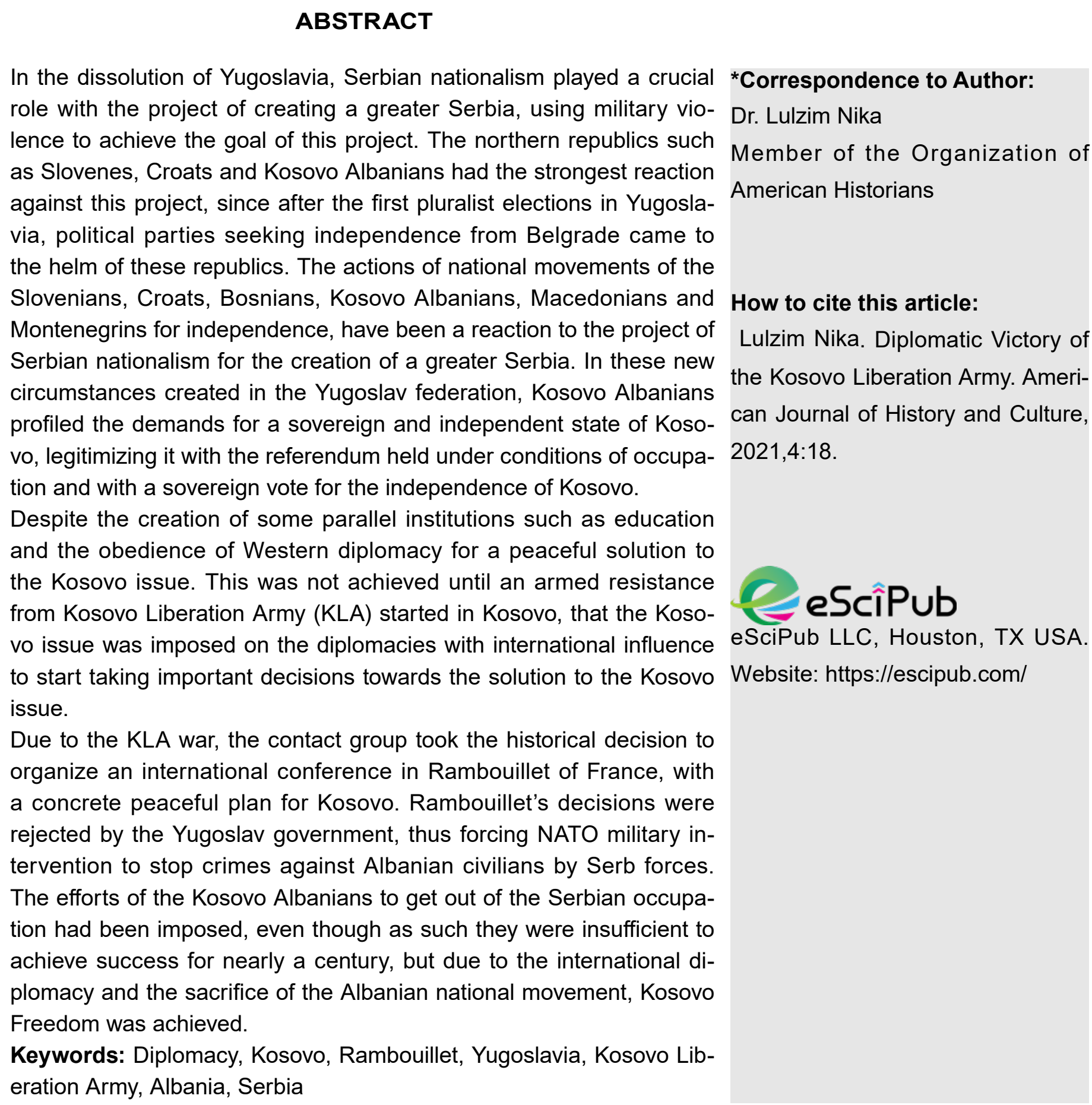


The Kosovo Liberation Army occupies a special place in the recent history of Kosovo not only for the dynamics it gave to the freedom movement within Kosovo, but also for the engagement of influential international diplomacy in resolving the Kosovo issue. After allowing political pluralism and the formation of political parties of the peoples living in the Yugoslav federation, the republics were led by parties seeking full independence from Belgrade. The Slovenes and Croats began to demand peaceful secession from the Yugoslav federation, whose demand sparked several years of bloody conflict in the former Yugoslavia. Kosovo at this time was under a violent administration of Serbia after gaining limited autonomy in 1974 . The formation of Albanian political parties in Kosovo began to profile the rightful demands of the Albanians demanding equality with other peoples. An analysis of American services in the 1990s had predicted this future of the Yugoslav federation:

The dissatisfaction of Kosovo Albanians was predicted in a general uprising that would last for several years and maybe even close to a decade. Anticipating that the Albanians would be armed mainly by the Albanian state, which had a predominantly Soviet and Chinese armament, which was difficult to quickly put forward in the desire of the Kosovo Albanians to withdraw Serbian forces ${ }^{2}$.

Although there were some organizations of Kosovo Albanians for armed resistance that also had some agreements with the Albanian state for support in the just fight for freedom. This idea was not supported by the diplomacy of the time and was especially opposed by the AngloAmericans, seeing it as a danger and an opportunity for Serbia to use them as a pretext for the ethnic cleansing of Kosovo. The diplomats of the time were informed about the plans of the Albanians and the goings to Albania, which were also organized by the Kosovo Albanian parties and especially by the Albanian diaspora, the last one being more vocal in the request for the opening of the southern front,
A Transformed Yugoslavia, Yugoslavia would cease to function as a federal state within a year, and would probably split within two. Economic reform would not avoid the division.

- Serbia will bllok the Slovenes and Croats attempts to form a confederation of all the Yugoslavs.

- There will be prolonged armed revolts from the Albanians in Kosovo. An interethnick war on a full scale was not likely, but a serious conflict inter-ethnick will accompany the dissolution and the violence will continue which will be unreturnable and bitter.

- There are very few chances that the United States and its European allies could preserve the Yugoslav unity. The Yugoslavs will see their attempts as contradictory to the perseverance of democracy and self-determination...

seeing as ideal cases to seize the moment when Serbs will face Croats and Bosniaks. Based on the research done in some documents of the time, it turns out that the diplomacies of the time were the ones that influenced the postponement of the opening of the conflict in Kosovo during the years 1991-1992, by not supporting it and asking the leader of the Kosovo Albanians to 'condemn these activities of armed groups that will not be in favor of a fair solution to Kosovo' $s$ political status. This was stated in 1992 by the British Secretary Douglas Hurd, at a meeting of the EC in Brussels, "yesterday after visiting Albania and Yugoslavia, the situation in Kosovo could explode and a catastrophe would occur in case of conflict." 3

In November 1997, the KLA appeared for the first time in uniform at a public manifestation. The cause was the murder of the teacher from Llausha, Drenica, Halit Geci, at whose funeral the KLA soldiers, disguised until then, seemed to most Balkan observers to have been a longawaited event. ${ }^{4}$ Internally, it brought the Kosovo issue to the forefront of the international powers' agenda of fair resolving centuries-old injustices 
against Albanians. The historic turning point of international engagement for Kosovo is the political and military factor that did not compromise without Kosovo's freedom despite warnings from international diplomats that they would not have their support for an armed war.

Until the emergence of the KLA, Albanians for years had focused on recognizing and raising public awareness of the Kosovo problem but had no significant effect on changing the situation in Kosovo.

They were the signs of the beginning of the armed war against Serbia. Milosevic and his regime continue to keep Kosovo under violent measures, or rather to say under a militarypolice state of emergency, where in 1995 alone, Serb forces arbitrarily killed 11 Albanians, wounded 11 others, and 2,500 Kosovo Albanians had been arrested, beaten and illtreated in most cases, and according to Human Rights Watch, Serbia kept Kosovo under control by committing deliberate, large-scale and organized human rights violations of the Kosovo Albanians, pushing them towards armed selfdefense. ${ }^{5}$

After the conflicts in Slovenia, Croatia and Bosnia, even the Kosovo Albanians were aware that with Milosevic it was difficult to find a peaceful solution to Kosovo's status. During 1991, but especially in 1992, an agreement was reached in principle with the Albanian state and the Government of Kosovo, to assist Kosovo Albanians in the event of a conflict in Kosovo. ${ }^{6}$ In a CIA analysis of 1992-1993, a detailed analysis was made of the military power of the Albanian state and it was concluded that with those capabilities, it was impossible to oppose the military power of Serbia. ${ }^{7}$ US diplomats suggested in meetings with Kosovo Albanian political representatives not to support the opening of the southern front in any way because the consequences for Kosovo Albanians would be unpredictable with an Albania lacking technical capacity and modern military technology. For this reason, the Americans were adamant in their positions on
Kosovo that the Kosovo issue should only seek to be resolved in the peaceful way, and other forms would not be supported. ${ }^{8}$ The Albanian armed groups, although organized during 1991, such as the group of Adem Jashari from Drenica, were not supported by the politics of official Tirana, and later not even that of Pristina. Based on the analysis of the time, it is seen that the disintegration of Yugoslavia would start from the north to the south, in order for the consequences to be smaller for the civilian population. From this analysis, Kosovo remains last on the international negotiating table for the settlement of political status. In a 1995 analysis by the Balkans Analysis Directorate, Strobe Talbott described Kosovo as a top US interes. ${ }^{9}$ Even the last American ambassador to Yugoslavia had suggested to Ibrahim Rugova that the most important thing is to protect the people of Kosovo in these circumstances, from any organized and planned massacre of the state of Serbia.

This was told to I. Rugova even in the meeting with the Secretary of State, at the NATO headquarters in December 1992, that Serbia should not be provoked by the Albanians in any way, in these circumstances. After the meeting, Rugova states that the Americans do not ask to give up our demands for independence but they ask the Kosovo Albanians to be careful. The liberation movement as a unifying movement of all forms of active resistance, has been continuously present in the lives of Kosovo Albanians.

After the pressures and state violence organized by the Yugoslav occupier against the illegal Albanian patriotic movements in Kosovo, they were forced to extend their activity to the west by organizing demonstrations and activities against the Yugoslav state.

How dangerous was the activity of Albanian patriotic organizations in the west is also proved by the organized action of the Yugoslav secret service that killed some of the leaders of these movements in Germany in January 1982, such as the murders of Kadri Zeka and Jusuf and Bardhosh Gervalla. 
The meeting of the leaders of the Albanian illegal organizations in the west aimed at uniting them in an organization and a common front to oppose the invading policy of the Yugoslav state that exercised violence and brutality against the Albanian population in Kosovo.

The unification of the Albanian movements fighting for the freedom of Kosovo was seen as a danger by the Yugoslav service which organized actions in Kosovo and in the west for the killing of some activists of the movements fighting for the freedom of Kosovo.

Since the mid-1980s, in the west there was an influential organization in the new Albanian diaspora, known by the acronym PMK ( People's Movement of Kosovo - LPK), which inherited the stance for a new union of Albanians. ${ }^{10}$ In April 1985, the amalgamation of illegal groups took place. Fehmi Lladrovci was chosen to deal with the military organization of the guerrilla war as a beginning up to the massification in the Frontal War for the freedom of the Albanian lands occupied by Yugoslavia. Fehmiu was in coordination with many illegal idealists of the time who believed that only by organizing armed resistance would Kosovo gain freedom, which at the time seemed so impossible, given the military and political power of Yugoslavia.

Since 1992, the liberation movement has been characterized by successive actions against the Serbian militia stationed in Kosovo. The first actions of the KLA are related to the end of 1992 and the beginning of 1993. The announcements of the first actions of the KLA were not published in the Albanian press, until the 20th announcement. In Belgrade, the KLA was described as a "terrorist force".

On April 27, 1998, when the KLA war in Kosovo had begun to take shape, the General Staff of the KLA issued a political statement declaring ... The KLA war has a defensive and liberating character ... The KLA condemns by force terrorism and other forms of violence against the civilian population ... will respect all international conventions of War ... The KLA belongs and will belong to the people ... ${ }^{11}$
In 1996 "The General Staff of the KLA published a bulletin, in which it recognized its actions and published comments on the political events of the day." 12 In May 1997, a group of boys who believed in the ideal of freedom through armed warfare and were determined on the road to liberation, all united in Tirana, decided to enter Kosovo to help KLA units operating in Kosovo.

The year 1996 and especially 1997, marks an activity organized with actions and announcements of the KLA throughout Kosovo. The fall of the hero Luan Haradinaj in May 1997, sensitized the international public that the political course of Kosovo Albanians who had been ignored by international conferences for a peaceful solution had changed. Peace policy had lost the support of some Albanians who did not hope for a peaceful solution to the Kosovo problem. The KLA initially encountered resistance from Albanian politics in both Pristina and Tirana, denying the existence of an organized armed group. The statements of Western diplomats and some local leaders were in denial and harsh approach to the activities and actions of the KLA, as evidenced by the letter addressed to President Clinton by the Prime Minister of Kosovo, during 1993. This letter shows that they lacked information on the early action of the KLA, which they saw as actions of rival Serbian groups that wanted to destabilize Kosovo. ${ }^{13}$

In the absence of courage and work of the Government of Kosovo to organize the armed warfare for the freedom of Kosovo that was mandated and had all the possibilities for organization, this work was taken over and organized by the People's Movement of Kosovo. The government of Kosovo in exile generally had to protect the Albanian people in Kosovo, but unfortunately this role was not only played by its late organization as it created divisions for the primacy of organizing the war in Kosovo. But, it was Adem Demaçi who first admitted, in December 1997, the existence of the KLA, at the time when there was uncertainty among politicians about the existence of the KLA. ${ }^{14}$ 
On February 28, 1998, after a dynamization of international diplomacy visiting Tirana and, suggesting a restrained policy behind the actions of the KLA. On the same day, the Minister of Foreign Affairs of Albania, in order to learn more about the KLA, in Munich, Germany, meets with Fehmi Lladrovci, the diplomat and the first man in charge of the Movement for the Organization of the Armed War in Kosovo. ${ }^{15}$ "Lladrovci informed me that armed actions and acts in Kosovo will not stop but will only lead to massification. ${ }^{16}$ On the same day, I received the news of the massacre of Likoshan and Qirez, after leaving the meeting with Fehmiu, where many Albanian civilians had suffered, including children and a pregnant woman who had been massacred by the Serbian police forces. ${ }^{17}$

The first Serbian offensive against the KLA began in March 1998, described as an "ethnic war" modeled on the wars in Bosnia and Croatia. In May 1998, the US-mediated Kosovo delegation met in Belgrade with Milosevic to then open the doors for the first time to a meeting at the White House Oval Office and be received by President Bill Clinton, the delegation was led by the Leader of the Kosovo Albanians Ibrahim Rugova, ( written on the White House agenda in Washington, May 26, 1998). In early June, S. Milosevic traveled to Moscow to brief Russian President Boris Yeltsin on Kosovo. He had promised to respect the March Resolution and the decisions of the Contact Group for negotiations on Kosovo's autonomy. Milosevic had promised B. Yeltsin that he would eliminate the Kosovo Liberation Army and would not be a political factor as the Americans wanted. Facing the summer offensive of 1998 was crucial for Kosovo and the Kosovo Liberation Army. In the same month and year, the Americans had decided to politically legitimize the KLA representatives. As a result of these offensives, according to UN data, in the autumn of 1998, 230,000 people fled Kosovo. Not a war against the KLA, but first of all terror and expulsion of the Albanian population, was the real goal of the Serbian war. The ethnic composition in Kosovo had to change forever and this could only be done through terror and brutal violence, which was also foreseen by the great Serb program. ${ }^{18}$ The KLA went through an arduous path of growth, until in March 1998, it took on wide proportions. From various foreign anti-Albanian circles, it was described with different names such as: "Group of frustrated people", "united by despair", etc. But the KLA was recognized for the first time as an important political factor by the US political administration at the June 19, 1998 meeting of the US National Security Council, where, among other things, a decision was made that the KLA would be part of the negotiations for the future of Kosovo. ${ }^{19}$ The first spokesman of the KLA, one of the prominent figures for patriotic activities even from before, became Jakup Krasniqi. 20 The fair and determined warfare of the KLA gave it international legitimacy by making it a decisionmaking factor as an internationally recognized movement. ${ }^{21}$

The KLA became the catalyst for events in Kosovo. It accelerated the perception of the crisis, more than ever before, for a real and longterm solution..$^{22}$ Initially, the people engaged in the KLA were few, the most devoted, the bravest, the ones with the most sacrifices, the most conscientious, mostly members of the LPK. 23

In 1992, Kosovo had its first armed formation, with Commander Adem Jashari, in Prekaz of Drenica, in this "Nursery of Albanian insurgents". Shaban Jashari's tower was the pivot around which all armed formations would be tied. ${ }^{24}$ The coordination of armed attacks, the deployment of the KLA and successful actions against the enemy militia were the fruit of the work and dream of Commander Adem Jashari.

On March 5, 6, and 7, 1998, the siege of the Jashari towers by the Serbian army and police was the final act to start the liberation war with the message given by Commander Adem Jashari. This is the greatest and most glorious epic, but also the most tragic of the KLA. The fall of the Legendary Commander, the family 
sacrifice of the legendary Jashar, opened a new era of glory and tragedy in our new history. ${ }^{25}$

As the world moved towards the democratic spirit of integration between peoples, Serbia with fascist methods and genocides aimed to benefit through Garashaninit and Cubrilovic's plans to exterminate the Albanians. The killings done by the Serbs in Kosovo brought to mind the killings in Bosnia and Herzegovina. ${ }^{26}$ But, KLA units had already occupied the mountains. The best sons of Kosovo were winning the battles with their blood. The first free zones were created, from where the voice of "Free Kosovo " was heard for the first time. In the confrontation with the KLA, in different locations of Kosovo, the Serbian army killed innocent people with criminal cynicism, burned and destroyed anything that was Albanian. Following the Serbian offensive in the summer and autumn of 1998, the Serbian government declared that it had succeeded in destroying the KLA throughout Kosovo. However, this did not happen despite the massacres of the Serbian army against Albanian civilians. We remember one of the bloodiest massacres, that of September 1998 in Obri, where even a 6-month-old baby was massacred. In such historical, social, political and national circumstances, the KLA began to spread throughout Kosovo. KLA soldiers took care of the people left in the open air before the Serbian paramilitary forces, although with the readiness and courage to face the occupier, its capabilities were insufficient to resist the Serbian military machinery. International diplomacy and the democratic world reacted against the Serbian government seeking a peaceful solution for Kosovo. The liberation war was evidence of the advancement of the demands and determination of Kosovo Albanians for independence, in response to the ethnic cleansing exercised by the Serbian occupier.

Thanks to the determination and important decisions of international diplomacy with political representatives of the KLA, came the right decision that Serbian aggression against the defenseless civilian population should be stopped even with the intervention of international forces against the Serbian military machinery that used violence against unprotected civilians throughout Kosovo.

There were several international diplomacy's decisions calling on the Yugoslav government to end the violence of military machinery against defenseless civilians in Kosovo. The Yugoslav government did not implement the requests, visits and decisions of international diplomats on the ground but continued with massacres against Albanian civilians in Kosovo.

Non-compliance with these decisions forced international diplomacy to legitimize the use of military force to stop the violence of Serb forces and ethnic cleansing of Kosovo Albanians.

NATO intervention in Kosovo was legitimized under the Chapter 7 of the Security Council, that when a state uses ethnic cleansing against the population it administers, it legitimizes the right to intervene in the salvation of an entire people. As in the case of Kosovo Albanians.

At the same time, world diplomacy led by the US and NATO, tracked the barbaric and murderous actions of the Serbian army and paramilitary forces of the Serbian regime against the people of Kosovo. The brutality of the Serbian forces on one hand, and the liberation war of the people of Kosovo on the other, accelerated the arrival of international delegations to get directly acquainted with the war in Kosovo. The US and the EU called for an end to Serbian repression. The Milosevic-Holbrooke agreement was also signed on October 13, 1998 in Belgrade, defining it as a possible turning point in the crisis. 27

The 11-point agreement had the full support of NATO and the Contact Group, including Russia. For many reasons this is considered a very big achievement. According to this agreement, Kosovo airspace would be controlled by NATO.As it had never happened before, 2,000 OSCE observers will operate in Kosovo. ${ }^{28}$ The Albanian refugees would return and the political process for solving the problem would begin. ${ }^{29}$ 
The Russian newspaper "Niezavisimaja Gazeta", in an article of 27 October 1998, emphasizes the statements of Generals Clark and Nauman regarding the safety of observers, who made it clear to Milosevic that they would be protected from NATO aviation. The agreement also allowed the arrival of the international diplomatic mission KDOM, which operated under the political leadership of the ambassadors of the Contact Group, the Austrian ambassador to Belgrade, as Austria was chairing the EU. Through intelligence sources as well as other sources, KDOM would understand about current or future combat zones, including atrocities against civilians. ${ }^{30}$ Following the Milosevic-Holbrooke Agreement, KDOM became the Kosovo Verification Mission. ${ }^{31}$

The Holbrooke Agreement of October 1998, which also enabled the arrival of international observers in Kosovo, was also in favor of a stronger organization of the KLA, which after the Serbian offensive in the summer of 1998 had lost significant leaders that had worked on its strategy to resist Serbian forces.

While the ceasefire was being considered, the Serbs were constantly launching military offensives against the population of Kosovo. It is said that the non-compliance with the agreement was a consequence of the non-involvement of the KLA as a party to this agreement. ${ }^{32}$ This was also the weakest point of this agreement. ${ }^{33} \mathrm{At}$ this time, eight Serb soldiers were arrested by KLA units, who were released only with the mediation of the internationals and conditioned on the release of KLA soldiers. This was a great victory for the KLA, as Serbia was forced to accept it as a party even in front of the internationals. About this in his book, Jakup Krasniqi, wrote: "This case has been one of the most difficult in my life; if the KLA soldiers had not been released, I would have resigned ..." 34

I think it is worth noting that despite the massacres and destruction of many residents by Serb forces in Kosovo, the Albanian political factor was divided. US diplomats R. Holbrooke and $\mathrm{K}$. Hill made efforts to form a Kosovo delegation for talks with Belgrade, but the disruption of the political spectrum in Kosovo was very emphasized and there was a lack of a serious address in Pristina for Western and American diplomats. I. Rugova claimed that he had the proper confirmation from the contested elections that had been held, while the two parties led by Rexhep Qosja, respectively Adem Demaçi and the KLA, demanded a broad involvement. The lack of good coordination of the political spectrum in Kosovo during June, July and September, I think, made K. Hill came back closer to the LDK leader, especially after Holbrooke threatened that they could leave. Rugova responded "if you say that Demaçi should be at the head of that Council, I have nothing against it." ${ }^{35}$ On June 19, 1998, the National Security Council in the presence of all representatives of US Government institutions, made the historic decision for the KLA that its representatives would be part of the Kosovo status negotiations. ${ }^{36}$ With this decision, Ibrahim Rugova was informed that in the negotiating group, the political representation of the Kosovo Liberation Army should be included. In early June, the US envoy to Kosovo, Christopher Hill, met in Malisheva with representatives of the $\mathrm{KLA}$, and after that meeting, he decided that the KLA should have its own representatives, and that the current parties in Pristina can not represent the KLA. The non-unity of the Albanian political factor was very unacceptable even for the representatives of the American government who were determined to resolve the political status of the Kosovo Albanians who, in spite of their efforts against Serbia, found it almost impossible to force them to withdraw from Kosovo. Even Rugova's political opponents lacked proper coordination and unity. The attempt on the proposal to lead a government that would include the entire political and military spectrum of Kosovo Albanians failed because of disagreements and controversial statements. Only after the relentless efforts of American diplomats was an agreement reached on the formation of a Kosovo-wide negotiating group on 
the political spectrum. On September 26, in the village of Obri e Eperme, Serbian police forces massacred 21 members of the Deliu family. The news of the event hit the front page of the New York Times on September 30, 1998. On the same day, a meeting was held at the White House, where Albright stated that " ... the photographs of the masacre reminded Srebrenica and that they knew they should not allow such crimes to be repeated." 37 On November 3, 1998, ambasador Hill invited the Kosovo Albanian leader, I. Rugova, in his car to visit some war-torn villages in Malisheva. "People were reluctant at first to see their leader for the first time after more than a decade. Then they approached and threw themselves on his arms, greeting ... I stopped to capture the view in its entirety ... On the same day I saw that Ibrahim Rugova was a force to be reckoned with and maybe that was the reason why the KLA and others were so harsh with him. "38 During 1998, the American diplomat had offered some concrete plans for the status of Kosovo to the Albanian side as well as to the Serbian government, where Kosovo would be given autonomous powers while maintaining a small Serbian military presence in Kosovo.

These plans did not endanger Serbian sovereignty in Kosovo and did not talk about any possibility of a referendum, after a certain deadline, where the majority population of Kosovo would declare independence.

These peace plans of the international mediators that did not guarantee the independence of Kosovo were unacceptable by the delegation of Kosovo Albanians, because all the peace plans offered by the international mediator during 1998 saved the Yugoslav sovereignty over Kosovo. The International Court of Justice in the evaluation of the international right to independence of Kosovo was PRO for the independence of Kosovo.

The dissolution of the former Yugoslav federation had created the legal basis for Kosovo's independence, as Kosovo in the 1974 constitution had become a constituent element of the Yugoslav federation. ${ }^{39}$

\section{References}

1. Yugoslavia Transformed, 18 October 1990 (Continued...) Director of Central Intelligence NIE 15-90 Yugoslavia Transformed Information available as of 18 October 1990 was used in the preparation of this National Intelligence Estimate. The following intelligence organizations participated in the pre-para-tion of this Estimate: The Central Intelligence Agency The Defense Intelli-gence Agency The National Security Agency The Bureau of Intelligence and Research. Department of State also participating: The Deputy Chief of Staff for Intelligence, Department of the Army The Assistant Chief of Staff, Intelli-gence. Department of the Air Force This Estimate was approved for publica-tion by the National Foreign Intelligence Board

2. Directorate of Intelligence Intelligence Memorandum Office of European Analysis 5 January 1993 Albanian Armed Forces: Unprepared for Confronta-tion with Serbia

3. INDEPENDENT, Carrington on mission to avert war in Kosovo,21 jul 1992, Diplomatic Editor

4. James Pettifer, Ushtria Çlirimtare e Kosovës, Nga një luftë e fshehtë në një kryengritje të Ballkanit 1948-2001 f.127, Shtëpia Botuese Onufri, Tiranë,2013.

5. Human Rights Watch Raporti Botëror botuar 1996-Kosova.

6. Arkivi i Ministrisë së Punëve të Jashtme e Republikës së Shqipërisë, Fondi Kosova në vitin1991/92,Dosja, nr 1609, B. 1608,V11/2

7. Directorate of Intelligence Intelligence Memorandum Office of European Ana-lysis 5 January 1993 Albanian Armed Forces: Unprepared for Confron-ta-tion with Serbia

8. Intelligence Report DCI Interagency Balkan Task Force 21 December 1995 Balkan Conflict Spillover Unlikely in Near Term Kosovo.

9. MEMORANDUM FOR: The Director of Central Intelligence FROM: Acting Director of $\mathrm{DCl}$ Interagency Balkan Task Force SUBJECT: Principals' Committee Meeting, 15 August, 1530, 1996,White House Situation Room The Principals may discuss whether to reissue Bush's Christmas demarche on Kosovo in which the US threatened to bomb the Serbs if there was a severe crackdown in Kosovo. Strobe Talbott described Kosovo as being of "supreme national interest to the US." 
10. Akademia e Shkencave e Shqipërisë, Kosova në vështrim enciklopedik, vep. e cit., f.132.

11. James Pettifer, Ushtria Çlirimtare e Kosovës, Nga një luftë e fshehtë në një kryengritje të Ballkanit 1948-2001 f.317,318, Shtëpia Botuese Onufri, Tira-në,2013.

12. Volfgang Petritsch, Robert Pihler, Rruga e gjatë në luftë, vep. e cit., f. 86.

13. Government of the Republic of Kosova, 38000 Prishtinë, Kosova, 25 May 1993, The Honorable Bill Klinton President The United States of America Washington, D.C, Prime Minister Kosova Dr.Bujar Bukoshi,DTG252/302

14. Po aty, f.88.

15. www.Rubikoni.com, KTV, intervistë, Xhavit Haliti, 2011.

16. Deklerata e Fehmi Lladrovcit për BBC në: Do të ishte nder madh,të vdes për Kosovën, Maj 1998, BBC

17. Instituti i Historisë-Prishtinë, Kumtesë në Konferencën shkencore ndër $\neg$ kom $\neg$ bëtare Jasharajt dhe lufta çlirimtare mars 2018, Paskal Milo (ish- Ministër i Punëve të Jashtme të Shqipërisë) Mars 2018

18. Joschka Fischer, Vitet kuq-gjelbër, vep. e cit., f. 100.

19. National Security Council, Washington D.C, Meeting of the NSC Principals Committee on Kosovo Date: June 19, 1998,.Subject: Summary of Conclusion of Principals Committee on Kosovo

20. Akademia e Shkencave e Shqipërisë, Kosova në vështrim enciklopedik, vep. e cit.,f. 35.

21. Edita Tahiri, Konferenca e Rambujesë,vep. e cit., f. 23.

22. Paskal Milo, Kosova nga Rambuje në pavarësi, "Toena", Tiranë, 2009, f. 72.

23. Ramë Buja, Çështja e Kosovës dhe shkatërrimi i Jugosllavisë, vep. e cit., f. 313.

24. Jakup Krasniqi, Kthesa e madhe, "Buzuku", Prishtinë, 2006, f. 20.

25. Jakup Krasniqi, Kthesa e Madhe, vep. e cit., f. 24.

26. Bill Klinton, Jeta ime,“Dudaj”, Tiranë, 2005, f. 712.

27. Volfgang Petritsch, Robert Pihler, vep. e cit., f. 129.

28. National Archives and Record Administration William J Klinton Presidencial Library, Little Rock, AR, USA, ID, Nuber, 1706, ducument ID Kosovo, Presidential Brifinng, Material and Background information, oct-98

29. Shaqir Vukaj, Rusia dhe Kosova, "Enriko Koço", Tiranë, 2007, f. 193.
30. Marc Weller, Shtetësia e kontestuar, vep. e cit., f. 160.

31. Volfgang Petritsch, Robert Pihler, Rruga e gjatë në luftë, vep. e cit., f. 110.

32. Joschka Fischer, Vitet kuq-gjelbër, vep. e cit., f. 116.

33. Volfgang Petritsch, Robert Pihler, Rruga e gjatë në luftë,vep. e cit., f. 140

34. Jakup Krasniqi, Kthesa e madhe, vep. e cit., f. 24.

35. Blerim Shala, Libri i Fitores,vellimi i parë, Koha,2012, f.116

36. National Security Council, Washington D.C, Meeting of the NSC Principals Committee on Kosovo. Date: Jun19, 1998.Subject: Summary of Conclusion of Principals Committee on Kosovo

37. Dario Malnar, SHBA-ja dhe Kosova,Koha, Prishtinë, 2013, f.176

38. Christopher R. Hill, Outpost Life on the Frontlines of American Diplomacy, Simon \& Schuster, New York, f.143,144. 